\title{
Soil Microbial Biomass Carbon under Rhizosphere and Non- Rhizosphere of Maize after a Long-Term Nitrogen Fertilization and Tillage Systems
}

\author{
Dermiyati, Eva Firdaus, Muhajir Utomo, Mas Achmad Syamsul Arif, and Sutopo Ghani Nugroho \\ Department of Soil Science, Faculty of Agriculture, University of Lampung Jl. Soemantri Brojonegoro No. 1, \\ Bandar Lampung INDONESIA 35145, phone/fax.: +62-721-781822, e-mail: dermiyati@unila.ac.id
}

Received 17 June 2010 / accepted 24 December 2010

\begin{abstract}
This research aimed to study the soil microbial biomass carbon (SMBC) under maize plant after a long-term application of nitrogen fertilizer and tillage systems (at the $37^{\text {th }}$ growing season). The treatments were arranged in a factorial $(3 \times 3)$ in a randomized completely block design with 3 replications. The first factor was tillage systems, namely intensive tillage (IT) system, minimum tillage (MT) system, and no tillage (NT) system, and the second factor was the long-term application of nitrogen fertilizer, namely 0,100 , and $200 \mathrm{~kg} \mathrm{~N} \mathrm{ha}^{-1}$. Data were analyzed using an orthogonal contrast test and a correlation test between SMBC and organic-C, total-N, and pH of the soil. The results showed that, in the rhizosphere and non-rhizosphere of maize plant, MT system increased the SMBC compared to NT and IT systems. However, application of long-term application of nitrogen fertilizer did not increase the SMBC. Nevertheless, fertilizer application of $100 \mathrm{~kg} \mathrm{~N} \mathrm{ha}^{-1}$ increased the SMBC compare to $200 \mathrm{~kg} \mathrm{~N} \mathrm{ha}^{-1}$. Furthermore, the combination of MT system and $100 \mathrm{~kg} \mathrm{~N} \mathrm{ha}^{-1}$ could increase the SMBC compared to the other combined treatment between tillage systems and $\mathrm{N}$ fertilization doses. The SMBC was higher in the rhizosphere than in non-rhizosphere of maize plant.
\end{abstract}

Keywords: Non-rhizosphere, rhizosphere, soil microbial biomass carbon, tillage systems

\section{INTRODUCTION}

Maize (Zea mays L.), together with rice and wheat are the three important cereal crop in the world. The advantage of maize compared to other cereals are high production, easily processed, easily digestible, and less expensive. Maize was important sources of carbohydrate, protein, iron, vitamin B, and minerals (IITA, 2009). In addition to food and feed, maize is a source of energy (ethanol). Therefore, in the future, world maize demand will increase in associate to more limited reserves of fuel oil. Based on data from Center for Food Crop Research and Development (2007), a national productivity of maize was $3.4 \mathrm{t} \mathrm{ha}^{-1}$, while at the research level has reached 7-8 $\mathrm{tha}^{-1}$. The existence of this gap in the maize productivity, there are two important things that need to be observed: (1) there are opportunities for increasing production through the application of technology, (2) technology generated through research either has not been known or not fully applied by the farmers.

J Trop Soils, Vol. 15, No. 3, 2010: 63-68

ISSN 0852-257X
One technology that can be applied is a conservation tillage system. Compared to conventional tillage (intensive tillage, IT) system, a conservation tillage system in the form of minimum tillage (MT) and no tillage (NT) systems which use mulch have the advantages that less of energy required, improving the soil structures, reducing the labor requirements, allowing the alley cropping, and lowering capital use (Lal 1990). Furthermore, Johanis (2008) states that conservation tillage is not only having the technical and economical advantages but also it can reduce greenhouse gas emissions and increase carbon sequestration in soil. A model developed in the USA showed that the conservation tillage system that could maintain the $30 \%$ of crop residues on the surface of agricultural land could neutralize $16 \%$ of fossil fuel emissions. This example is likely to emphasize that the transition from conventional tillage practices to the conservation tillage will significantly contribute in increasing the carbon deposits in the soil, which will directly improve soil fertility and reduce emission of methane in the atmosphere. This can be a contribution to the agricultural sector which is very meaningful in an 
effort to mitigate the risks of climate change due to global warming. Woods and Schuman (1988) stated that continuous cultivation of land in many years can reduce $\mathrm{C}$ mineralization and $\mathrm{N}$ potential. According to Sarno et al. (1998), levels of total-C in no tillage system were significantly increased compared to intensive tillage and minimum tillage systems. This is in agreement with Gonggo et al. (2005) which stated that soil tillage also caused a decreasing in soil organic-C, which apparently caused by soil cultivation resulted in higher weathering process of organic matter.

Carbon is a component of organic matter and microbial cell. Soil microbial biomass carbon can be used as an index of soil fertility. Soil which has a variety of soil microorganisms generally indicate that such soil is a good in its physical and chemical properties. The high population and the various types of soil microorganisms may be found only in the fertile soil that allows microorganisms to grow and to do their activities (Buchari 1999). Usually, the healthy rhizosphere ecosystems will be occupied by beneficial organisms that utilize organic substrates from organic material or plant exudates as a source of energy and nutrients (Hidersah and Sima, 2004). As stated by Subba Rao (1994), plant roots release exudates in the form of organic acids, amino acids, sugars, proteins, polysaccharides, and other compounds that have not been identified yet.

On the other hand, the size of the SMBC has been proposed as a sensitive indicator for measuring the adverse effects of contaminants on the soil microbial community. Broos et al. (2007), studied on Australian agricultural systems, demonstrated that field variability of SMBC measured using the fumigation-extraction procedure limited its use as a robust ecotoxicological endpoint. On the other hand, Manna and Singh (2001) stated that the average level of soil microbial biomass carbon was $1,158 \mathrm{~kg} \mathrm{ha}^{-1}(0-0.15 \mathrm{~m}$ depth$)$ and the organic carbon turnover rate was $8.5 \mathrm{yr}^{\text {"1 }}$ after 38 years of intercropped fruit trees, which resulted in a lower ratio (1.81) of carbon inputs to soil microbial biomass carbon. Moreover, Li et al. (2009) concluded that soil microbial biomass, enzyme and mineralization activities can be used as microbiological and biochemical indices that can provide a reliable and comprehensive indication of changes in soil quality and organic nutrient cycling.

Besides carbon, nitrogen is one of the macro nutrients that can be the main limiting factor for plant production. Halliday and Trenkel (1992) in Sirappa (2003), that nitrogen needed by maize plants ranged from 120 to $180 \mathrm{~kg} \mathrm{~N} \mathrm{ha}^{-1}$. Niswati et al. (1998) stated that $\mathrm{N}$ fertilization dosage of
$200 \mathrm{~kg} \mathrm{~N} \mathrm{ha}^{-1}$ increased the amount of soil mesofauna compared to 0 and $100 \mathrm{~kg} \mathrm{~N} \mathrm{ha}{ }^{-1}$. Furthermore, Sitompul and Purnomo (2004) reported that increasing of maize biomass was related to an increasing dose of $\mathrm{N}$ fertilizer that has an impact to increasing the $\mathrm{N}$ concentration and leaf area index.

This research aimed to study the effect of long-term application of nitrogen fertilizer and tillage systems on soil microbial biomass carbon in the rhizosphere and non-rhizosphere of maize plant.

\section{MATERIALS AND METHODS}

\section{Study Site}

The study was conducted in the Lampung Polytechnic Research Area that had been done longterm application of tillage systems and nitrogen fertilization from 1987 to 2007 and after that time the soil was fallowed for one year.

\section{Exprimental History}

This research was conducted in February to June 2008, which was the $37^{\text {th }}$ growing season. Cropping pattern applied were Serelia (corn and upland rice) and legumes (soybean, peanut, and green beans). $\mathrm{N}$ fertilization was only done on Serelia cropping. On the $17^{\text {th }}$ (in year 1997) and the $28^{\text {th }}$ (year 2002) growing seasons, the soil on the no tillage and minimum tillage treatment plot was re-tilled because it had been a decline in production caused by soil compaction. Due to a decreasing in soil $\mathrm{pH}$, on the $31^{\text {th }}$ growing season (in year 2004) an agricultural lime $\left(\mathrm{CaCO}_{3}\right)$ with a dose of $4 \mathrm{t} \mathrm{ha}^{-1}$ was applied in all treatment plots.

\section{Exprimental Design}

The treatments were arranged in a factorial (3 $\times 3$ ) in a randomized completely block design with 3 replications. The first factor was the tillage systems, namely intensive tillage (IT), minimum tillage (MT), and no tillage (NT), and the second factor was the long-term nitrogen fertilization, namely 0,100 , and $200 \mathrm{~kg} \mathrm{~N} \mathrm{ha}^{-1}$. The soil samples were taken in the non-rhizosphere and rhizosphere area of maize plants at harvesting time.

In the IT treatment, soil was tilled at the planting time and weed residues were removed from the experimental plots. In the NT and MT treatments, two weeks before the planting soil was sprayed using glyphosate herbicide with a dose of $4 \mathrm{~L} \mathrm{ha}^{-1}$ to eradicate weeds, then the weeds were 
used as mulch. There were 36 experimental plots in accordance to the treatments and the plot size was $4 \mathrm{~m} \times 6 \mathrm{~m}$ and the distance between plot was 1 $\mathrm{m}$. The distance between the planting hole was 25 $\mathrm{cm} \times 75 \mathrm{~cm}$, and maize varieties used were P-12. At one week planting period, fertilizers were given, namely urea (according to treatment doses of 0,100 , and $\left.200 \mathrm{~kg} \mathrm{~N} \mathrm{ha}^{-1}\right), \mathrm{SP}-36\left(100 \mathrm{~kg} \mathrm{ha}^{-1}\right)$ and $\mathrm{KCl}$ $\left(50 \mathrm{~kg} \mathrm{ha}^{-1}\right)$. Urea was applied in 3 stages, namely at the beginning of planting, one month after planting, and at the maximum vegetative growth. Plants were maintained by watering and weeding. Control of pests and diseases were taken whenever necessary.

At harvest, in each plot soil samples were taken randomly at four points with a depth of $0-20 \mathrm{~cm}$ and then mixed. The soil samples were taken in the non-rhizosphere and rhizosphere area. Soil microbial biomass carbon was measured by a soil microorganisms fumigation-incubation method (Jenkinson and Powlson 1976).

\section{Data Analysis}

Data were analyzed using ANOVA (analysis of variance) and continued by an orthogonal contrast test. A correlation test between SMBC and organic-C, total- $\mathrm{N}$, and $\mathrm{pH}$ of the soil was also done.

\section{RESULTS AND DISCUSSION}

The results of ANOVA in the non-rhizosphere and rhizosphere of maize plants (data not shown), that the soil tillage system and the long-term nitrogen fertilization significantly affected the SMBC, whereas the interaction between them did not significantly affect the SMBC.

The results of an orthogonal contrasts test in the non-rhizosphere and rhizosphere of maize plants (Table 1) show that the NT system did not significantly increase SMBC compared to the IT and MT systems. This was likely that soil compaction had occurred in the NT system which caused reducing oxygen $\left(\mathrm{O}_{2}\right)$ in the soil so that decreased the microorganism activities. According to Utomo (1995), there were more amount of maize roots when maize was cropped by NT system and the roots filled the macro pores space of the top soil layer. As the root growing, the soil particles were pressed so that condensed and eventually inhibited the soil microorganism activities. Furthermore, it was likely that because of the occurrence of soil compaction, the high soil organic$\mathrm{C}$ was found on the soil surface layer and decreased significantly with increasing soil depth. In this study soil samples were taken to a depth of $\pm 20 \mathrm{~cm}$ in that because soil organic-C in the NT system was low SMBC produced would also be low.

Table 1 also shows that MT system was significantly increased SMBC than NT and IT systems. The MT system had mulch that could be used as an additional organic material, so that microorganisms could grow and being active. Organic materials can be used as an energy source for the growth of soil microorganisms, in addition, soil organic matter can also maintain the soil moisture. In moist soil conditions, soil microorganisms are able to perform their activities optimally.

Table 1. An orthogonal contrast test of soil microbial biomass carbon ( $\left.\mathrm{mg} \mathrm{C}-\mathrm{CO}_{2} \mathrm{~kg} \mathrm{day}^{-1}\right)$ in the rhizosphere (R) and non-rhizosphere (S) of maize plant as the influence longterm application of $\mathrm{N}$ fertilization and tillage systems.

\begin{tabular}{|c|c|c|c|c|c|c|c|}
\hline & \multirow{2}{*}{ Contrast } & \multicolumn{2}{|c|}{ F-calculation } & \multicolumn{2}{|c|}{ Differences } & \multicolumn{2}{|c|}{$\%$ Different } \\
\hline & & $\mathrm{R}$ & $\mathrm{S}$ & $\mathrm{R}$ & $\bar{S}$ & $\mathrm{R}$ & $\mathrm{S}$ \\
\hline $\mathrm{C}_{1}$ : & $\mathrm{T}_{3} \mathrm{vs}_{2}, \mathrm{~T}_{1}$ & ns & $\mathrm{ns}$ & -30.5 & -17.1 & 5.3 & 9.2 \\
\hline $\mathrm{C}_{2}$ : & $\mathrm{T}_{3}$ vs $\mathrm{T}_{2}$ & $* *$ & $* *$ & -136.6 & -56.1 & 20.0 & 25.0 \\
\hline $\mathrm{C}_{3}$ : & $\mathrm{T}_{3} \mathrm{vs} \mathrm{T}_{1}$ & ns & ns & 75.6 & 21.9 & 16.1 & 15.0 \\
\hline $\mathrm{C}_{4}$ : & $\mathrm{T}_{2}$ vs $\mathrm{T}_{1}$ & $* *$ & $* *$ & 212.2 & 78.0 & 45.1 & 53.3 \\
\hline $\mathrm{C}_{5}$ : & $\mathrm{N}_{2}, \mathrm{~N}_{1}$ vs $\mathrm{N}_{0}$ & ns & ns & 52.4 & -12.2 & 9.9 & 6.5 \\
\hline $\mathrm{C}_{6}$ : & $\mathrm{N}_{2} \mathrm{vs} \mathrm{N}_{1}$ & $* *$ & $* *$ & -495.1 & -102.4 & 59.5 & 45.2 \\
\hline $\mathrm{C}_{7}:$ & $\mathrm{N}_{2}$ vs $\mathrm{N}_{0}$ & $* *$ & $* *$ & -195.1 & -63.4 & 36.7 & 33.8 \\
\hline $\mathrm{C}_{8}:$ & $\mathrm{T}_{3} \mathrm{~N}_{2}, \mathrm{~T}_{3} \mathrm{~N}_{1}$ vs others & ns & ns & -46.5 & -19.3 & 8.1 & 10.5 \\
\hline $\mathrm{C}_{9}:$ & $\mathrm{T}_{2} \mathrm{~N}_{1}$ vs others & $* *$ & $* *$ & 440.9 & 135.4 & 85.2 & 82.2 \\
\hline
\end{tabular}

Note: ns: non significant; **: highly significant, $\mathrm{N}_{0}: 0 \mathrm{~kg} \mathrm{~N} \mathrm{ha}^{-1} ; \mathrm{N}_{1}: 100 \mathrm{~kg} \mathrm{~N} \mathrm{ha}^{-1} ; \mathrm{N}_{2}: 200 \mathrm{~kg} \mathrm{~N} \mathrm{ha}^{-1}, \mathrm{~T}_{1}$ : Intensif Tillage (IT) system; $\mathrm{T}_{2}$ : Minimum Tillage (MT) system; $\mathrm{T}_{3}:$ No Tillage (NT) system. 
Furthermore, $\mathrm{N}$ fertilization (100 and $200 \mathrm{~kg}$ $\mathrm{N}$ ha $^{-1}$ ) did not significantly increase SMBC compared to control $\left(0 \mathrm{~kg} \mathrm{~N}^{-1}\right)$ (Table 1$)$. Meanwhile, $\mathrm{N}$ fertilization with a dose of 0 and 100 $\mathrm{kg} \mathrm{N} \mathrm{ha}^{-1}$ were significantly increased SMBC than a dose of $200 \mathrm{~kg} \mathrm{~N} \mathrm{ha}^{-1}$. It was likely that an excessive dose of $\mathrm{N}$ application would negatively affect the soil living microorganisms, so the SMBC produced would also be low.

On the contrary, several research found that long-term applications of $\mathrm{P}$ fertilizer was likely more affected soil microbial biomass carbon than long-term N fertilization. Zhong and Cai (2007) studied that a long-term application of inorganic fertilizers (13 years) for flooded double rice crops, the number of cultivable microorganisms was significantly larger, and microbial biomass and community functional diversity were significantly higher in the treatments fertilized with $\mathrm{P}$ than those in the treatments without $\mathrm{P}$ fertilization. However, stimulation by $\mathrm{N}$ application of microbial biomass and community functional diversity as well as rice crop yields could be achieved only after improvement of the $\mathrm{P}$ supply. Moreover, Chu et al. (2007) described the effects of balanced versus nutrient-deficiency fertilization on soil microbial biomass, activity, and bacterial community structure in a long-term (16 years) field experiment. Long-term fertilization greatly increased soil microbial biomass $\mathrm{C}$ and dehydrogenase activity, except that the Pdeficiency fertilization had no significant effect. They emphasized the importance of balancedfertilization, as well as the role of $\mathrm{P}$, in maintaining soil organic matter, and promoting the biomass and activity of microorganisms.

Furthermore, the combination of NT system and $\mathrm{N}$ fertilization doses of 100 and $200 \mathrm{~kg} \mathrm{~N} \mathrm{ha}^{-1}$ did not significantly increase SMBC as compared to other treatment combinations (Table 1). While the combination of MT system and $100 \mathrm{~kg} \mathrm{~N} \mathrm{ha}{ }^{-1}$ was significantly increased SMBC compared to other treatment combinations. This means that basically soil cultivation is important to be done to create suitable environmental conditions to enhance the growth of soil microorganisms. Yet if the soil was intensively cultivated it could be unfavorable for the growth of soil microorganisms because oxidation of organic materials occurred more rapid that resulted low soil organic carbon and biomass produced by soil microorganisms would also be low. According to Sutedjo et al. (1991), an organic matter that used as an organic fertilizer would go on a decomposition process and produced carbon, nitrogen nutrients, and organic acids that can be used as an additional energy for the microorganisms. The availability of adequate nutrient sources could increase the growth and the activity of soil microorganisms.

Table 2 shows that in general the SMBC in the rhizosphere soil was significantly higher than in non-rhizosphere with the R/S ratio ranged from 2.7 to 3.5 . This could mean that the lower the $\mathrm{R} / \mathrm{S}$ ratio, the fertile the soil was, because the development of microorganisms was not influenced by energy source that produced by root exudates. Conversely, if the R/S ratio high, the soil was categorized as less fertile as the development of soil microorganisms was relied on energy resources derived from root exudates alone.

There was a positive correlation between organic-C content and the SMBC in the rhizosphere and non-rhizosphere of maize (Table 3), which means that SMBC increased by increasing the content of organic-C in soil. However, the correlation value (r) in the rhizosphere $(0.70)$ was lower than in non-rhizosphere (0.91). This was likely that the microorganisms in the non-

Table 2. $\mathrm{T}$ test and $\mathrm{R} / \mathrm{S}$ ratio between soil microbial biomass carbon ( $\mathrm{mg} \mathrm{C}-\mathrm{CO}_{2} \mathrm{~kg}$ day $\left.{ }^{-1}\right)$ in the rhizosphere $(\mathrm{R})$ and non-rhizosphere $(\mathrm{S})$ of maize plant as the influence longterm application of $\mathrm{N}$ fertilization and tillage systems.

\begin{tabular}{lcccc}
\hline \multirow{2}{*}{ Treatment } & \multicolumn{2}{c}{ SMBC $\left(\mathrm{mg} \mathrm{C}-\mathrm{CO}_{2} \mathrm{~kg} \mathrm{day}^{-1}\right)$} & \multirow{2}{*}{ T- test } & R/S ratio \\
\cline { 2 - 3 } & Rizhospere $(\mathrm{R})$ & Non-Rhizosphere $(\mathrm{S})$ & & \\
\hline Urea 0 kg N ha $^{-1}$ & 531.7 & 187.8 & $7.16^{*}$ & 2.8 \\
Urea 100 kg N ha & 731.7 & 207.3 & $5.42^{*}$ & 3.5 \\
Urea 200 kg N ha & 336.6 & 124.4 & $3.41^{\mathrm{ns}}$ & 2.7 \\
Intensif Tillage & 470.7 & 146.3 & $2.49^{\mathrm{ns}}$ & 3.2 \\
Minimum Tillage & 682.9 & 224.4 & $4.55^{*}$ & 3.1 \\
No Tillage & 546.3 & 168.3 & $3.07^{\mathrm{ns}}$ & 3.2 \\
\hline
\end{tabular}

Note: ns: non significant; *:significant 
Table 3. A correlation test between soil microbial biomass carbon in the rhizosphere (R) and non-rhizosphere $(\mathrm{S})$ of maize plant as the influence long-term application of $\mathrm{N}$ fertilization and tillage systems.

\begin{tabular}{lcc}
\hline \multirow{2}{*}{ Variabel } & \multicolumn{2}{c}{ r value } \\
\cline { 2 - 3 } & $\begin{array}{c}\text { Rizhospere } \\
(\mathrm{R})\end{array}$ & $\begin{array}{c}\text { Non-Rhizosphere } \\
(\mathrm{S})\end{array}$ \\
\hline Organic-C & $0.70^{*}$ & $0.91^{\text {** }}$ \\
Total-N & $-0.12^{\mathrm{ns}}$ & $-0.21^{\mathrm{ns}}$ \\
Soil acidity $(\mathrm{pH})$ & $0.23^{\mathrm{ns}}$ & $0.30^{\mathrm{ns}}$ \\
\hline
\end{tabular}

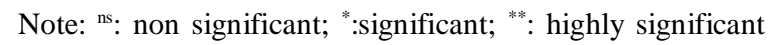

rhizosphere were more responsive to the organic$\mathrm{C}$ soil because they did not have other sources of energy. According to Buchari (1999), soil carbon was an important variable to stimulate the activity of soil microorganisms. The increasing of SMBC was likely to be influenced by the presence of carbon in root exudates.

\section{CONCLUSIONS}

Soil microbial biomass carbon (SMBC) in the rhizosphere and non-rhizosphere of maize plants higher in a minimum tillage (MT) system than in no tillage (NT) and intensive tillage (IT) systems. However, application of nitrogen fertilizer did not increase the SMBC. Nevertheless, application of $100 \mathrm{~kg} \mathrm{~N} \mathrm{ha}^{-1}$ increased more SMBC than $200 \mathrm{~kg}$ $\mathrm{N} \mathrm{ha}{ }^{-1}$. Furthermore, the combination of MT system and $100 \mathrm{~kg} \mathrm{~N}^{-1}$ increased more SMBC than the other combination treatments. SMBC was higher in the rhizosphere than in non-rhizosphere of maize plants.

\section{REFERENCES}

Broos K, LM Macdonald, MSJ Warne, DA Heemsbergen, MB Barnes, M Bell and MJ McLaughlin. 2007. Limitations of soil microbial biomass carbon as an indicator of soil pollution in the field. Soil Biol Biochem 39 (10): 26932695.

Buchari H. 1999. Determination of microbial carbon (C-mic) on two types of land use (coarse grass and forest) by fumigation-extraction method as an indicator of soil degradation. Graduate Program. Bogor Agricultural University, Bogor, 29 p.

Center for Food Crop Research and Development. 2007. Deploying technology, harvesting corn. Agric Res Develop News 29 (1): 1-3.
Chu H, X Lin, T Fujii, S Morimoto, K Yagi, J Hu and J Zhang. 2007. Soil microbial biomass, dehydrogenase activity, bacterial community structure in response to long-term fertilizer management. Soil Biol Biochem 39 (11): 29712976.

Gonggo BM, B Herman and D Anggraeni. 2005. Effect of cover crops and soil management on soil physical properties in the area of reeds. Indon J Agric Sci 7 (1): 44-50.

Hidersah R and T Simarmata, 2004. Azotobacter rhizobacteria potential in improving soil health. $J$. Nature Indon 5 (2): 127-133.

IITA [International Institute of Tropical Agriculture]. 2009 . w w w. i i ta.org/c m s/d e tail s/ maize_project_details.aspx?. Accessed at October 25, 2009.

Jenkinson DS and DS Powlson. 1976. The chlorofumigation method. Soil Biol Biochem 8 (10): 1547-1552.

Johanis ML. 2008. Global Warming and Agriculture Conservation. http://sinarharapan.go.id. Accessed at February 4, 2009.

Lal R. 1990. Erosion and Soil Degradation: The Global Risk. Adv in Soil Sci 11: 129-172.

Manna MC and MV Singh. 2001. Long-term effects of intercropping and bio-litter recycling on soil biological activity and fertility status of sub-tropical soils. Biores Techn 76 (2): 143-150.

Li YT, C Rouland, M Benedetti, FB Li, A Pando, P Lavelle and J Dai. 2009. Microbial biomass, enzyme and mineralization activity in relation to soil organic $\mathrm{C}, \mathrm{N}$ and $\mathrm{P}$ turnover influenced by acid metal stress. Soil Biol Biochem 41 (5): 969977.

Niswati A, M Utomo, MAS Arif and S Yusnaini. 1998. Long-term conservation tillage effects on soil mesofauna. Proceedings of the National Seminar. Unila Research Institute. Bandar Lampung, pp. 110146.

Sarno, S Yusnaini, Dermiyati and M Utomo. 1998. Effect of tillage system and long-term nitrogen fertilization of humic acid content and acid fulvik. J Trop Soils 7: 35-42.

Sirappa MP. 2003. Determination of critical limits and dose of $\mathrm{N}$ fertilizer for corn crops in dry land on the ground TypicUsthorthents. J Soil Environ Sci 2 (3): 25-37.

Sitompul SM and D Purnomo. 2004. Improved performance of corn and soybean crops in teak agroforestry system with nitrogen fertilization. Agrosains 2 (6): 79-83.

Subba Rao NS. 1994. Soil Microorganisms and Plant Growth. University of Indonesia Press, 353 p.

Sutedjo MM, AG Kartasapoetra and RDS Sastroatmodjo. 1991. Soil Microbiology. Melton Putra, Jakarta.

Utomo M. 1995. Violence soil and plant nutrient uptake of maize in long-term conservation tillage. J Trop Soils 1: 1-7. 
Woods LE and GE Schuman. 1988. Cultivation and slope position effects on soil organic matter. Soil Sci Soc Am J 52: 1371-1376.
Zhong WH and ZC Cai. 2007. Long-term effects of inorganic fertilizers on microbial biomass and community functional diversity in a paddy soil derived from quaternary red clay. Appl Soil Ecol 36 (2-3): 84-91. 